Original Article (short paper)

\title{
Time-course of health-related adaptations in response to combined training in hypertensive elderly: immune and autonomic modulation interactions
}

\author{
Amanda V. Sardeli ${ }^{1,2}$ (), Arthur F. Gáspari ${ }^{1}$ (1), Wellington M. dos $\operatorname{Santos}^{1}$ (1), \\ Daisa Fabiele G. Moraes ${ }^{1}$ (1), Victor B. Gadelha ${ }^{1}$ (), Lucas do C. Santos ${ }^{1}$ (D),

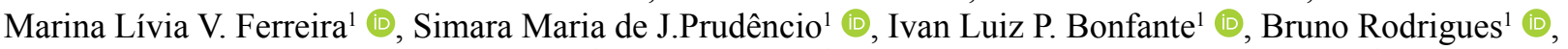 \\ Cláudia Regina Cavaglieri'1,2 (D), Bo Fernhall ${ }^{3}$ (D), Mara Patrícia T. Chacon-Mikahil1 ${ }^{1,2}$ (1) \\ ${ }^{1}$ Universidade Estadual de Campinas, UNICAMP, Laboratory of Exercise Physiology, Faculty of Physical \\ Education, Campinas, SP, Brazil, ${ }^{2}$ Universidade Estadual de Campinas, UNICAMP, Gerontology \\ Program, Faculty of Medical Sciences, Campinas, SP, Brazil; ${ }^{3}$ University of Illinois at Chicago, \\ Department of Kinesiology and Nutrition, College of Applied Health Sciences, Chicago,USA.
}

\begin{abstract}
Aims: This article is a methodological description of a randomized clinical trial (ClinicalTrials.gov U1111-1181-4455) aiming to evaluate the time-course (monthly) and associations between blood pressure changes and other health-related adaptations in response to exercise training in hypertensive elderly. Methods: The patients will be randomized to a control or combined training group interventions (aerobic and resistance exercise), with monthly assessments in four months. Although, the changes in baseline blood pressure is the primary clinical outcome, the secondary outcomes include: body composition, cardiorespiratory fitness, muscle strength, arterial stiffness, baroreceptor sensitivity, cardiovascular autonomic modulation, inflammatory markers, oxidative stress, growth factors, tissue remodeling markers, metabolic profile, renal function, cognitive function and quality of life. Results: To support the understanding of the blood pressure changes in hypertensive elderly, a time-course of exercise-induced adaptations including cardiovascular and immunological adaptations are fundamental for research in this field. Conclusion: To investigate the time-course of combined training-induced adaptations including all the diverse aspects of health in hypertensive elderly a well-controlled protocol design is necessary, mainly to clarify the relationship between cardiovascular and immunological exercise-induced adaptations.
\end{abstract}

Keywords: aging; hypertension; exercise; immune system; cardiovascular system.

\section{Introduction}

Cardiovascular diseases lead to nearly 17 million deaths per year worldwide, and 9.4 million of these deaths are attributed to hypertension ${ }^{1,2}$. The incidence of hypertension increases with $\mathrm{age}^{3}$, reaching $63.2 \%$ of the elderly population in $\mathrm{Brazil}^{4}$. The pathogenesis of hypertension is still unclear, with heterogeneous and multifactorial etiology, but it is influenced by the kidney function, cardiovascular autonomic modulation, endothelial function and the immune system (IS) $)^{5,6}$.

Recently, the IS and autonomic nervous systems have received attention regarding their influence in the genesis of hypertension. Both the IS and the autonomic nervous system control and interact with the other physiological systems and undergo remarkable changes during the aging process, including developing conditions such as low-grade chronic inflammation ${ }^{7,8}$ and cardiac autonomic modulation imbalance ${ }^{9,10}$. Low-grade chronic inflammation contributes to many chronic diseases common to the elderly, such as hypertension, atherosclerosis, diabetes, rheumatoid arthritis and frailty syndrome ${ }^{11,12}$. Likewise, autonomic modulation imbalance, as a result of elevated sympathetic modulation ${ }^{10}$ and reduced parasympathetic modulation ${ }^{9}$, also increases the risk of chronic diseases and mortality ${ }^{13,14}$. It is noteworthy, the evidence for the interaction between these systems is the presence of $\beta$-adrenergic receptors in immune system cells, such as T cells, B cells, natural killer cells, macrophages, and neutrophils, providing the molecular basis to catecholaminergic signaling ${ }^{15}$. In addition, Tracey ${ }^{16}$ showed that vagal stimulation is a potential inductor of antiinflammatory markers increase and/or inflammatory markers reduction. Moreover, recent evidence has shown the influence of IS cells and inflammatory cytokines on cardiovascular autonomic modulation nucleus in the central nervous system contributing to the development of hypertension ${ }^{17-19}$.

Figure 1 illustrates some factors related to the development and maintenance of hypertension adding the influence of physical training on the attenuation on these factors. Both aerobic training and resistance training promote immune adaptations and lower $\mathrm{BP}^{20,21}$. Regarding immune adaptations, some exerciseinduced anti-inflammatory mechanisms have been proposed and the most known is the reduction of adipose tissue which in turns reduces adipose pro-inflammatory cytokines ${ }^{20}$. Another mechanism proposed in the literature is coordinated by the induction of an anti-inflammatory environment after each exercise session, 
associated to the regulation of energy expenditure ${ }^{20,22}$. Furthermore, both aerobic and resistance training, as well as the combination of these exercises types, produce significant cardiovascular benefits, especially in sedentary and populations at increased cardiovascular risk. These benefits comprise improvements in the parasympathetic and sympathetic modulation of heart and vessels $^{23-25}$, baroreflex sensitivity ${ }^{26}$, central and peripheral arterial compliance $^{27-29}$, endothelial function ${ }^{30}$, as well as the specific reduction in blood pressure ${ }^{31-33}$. Moreover, some studies have shown the effects of physical training on autonomic modulation in parallel with the reduction of inflammatory markers in healthy adults and elderly ${ }^{34,35}$.

A significant study investigated the association of immune and autonomic systems in spontaneously hypertensive rats ${ }^{18}$. They found that aerobic training reduced inflammation in hypothalamic nuclei of cardiovascular control and increased baroreflex sensitivity after two weeks, increased parasympathetic modulation to the heart after 4 weeks, and reduced sympathetic modulation to the vessels and blood pressure after 8 weeks. However, hypertensive elderly develop hypertension with the association of multiple health conditions that might differ in some aspects from spontaneously hypertensive rats ${ }^{36}$. Furthermore, the time-course of these adaptations in humans is unknown.

This is the first randomized control trial able to describe the time-course of exercise-induced blood pressure changes in parallel to IS, autonomic modulation and a comprehensive assessment of health-related adaptations in elderly humans. Importantly, this study will investigate the effect of combined training, which shows promise for blood pressure reduction and it is recommended due to its essential and complementary benefits for elderly health ${ }^{6,37,38}$.

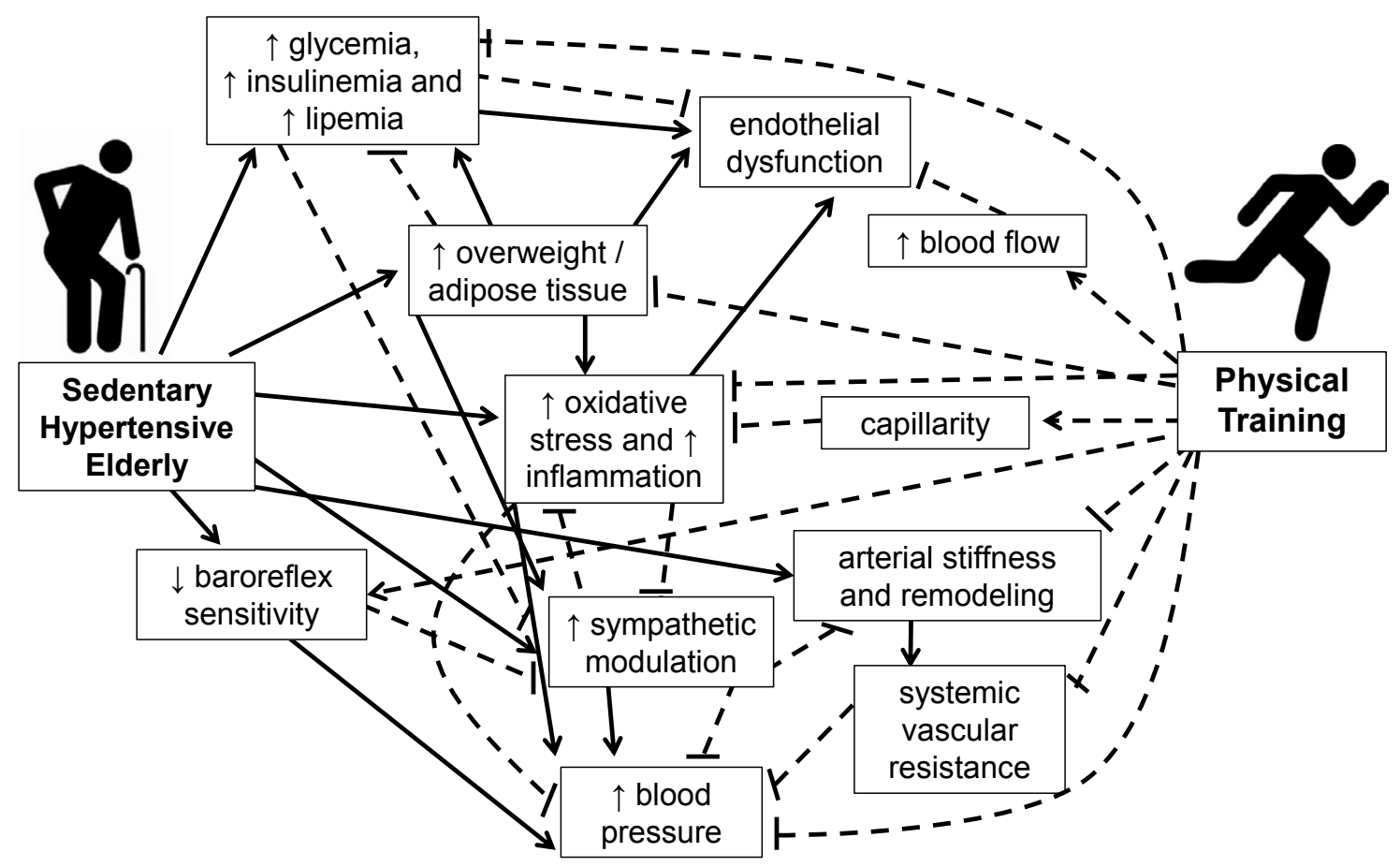

Figure 1. Interactions between alterations in sedentary hypertensive elderly individuals and the influence of physical training. The arrows represent the stimulus of the hypertensive condition (full line) and exercise (dashed line) on the changes indicated inside the rectangles, while the dashed lines ending with transverse lines represent inhibition for a given change.

\section{Methods}

\section{Subjects}

The elderly hypertensives (over 60 years old) will be randomized to a control group (without intervention) or 4 months of combined exercise training, according to figure 2 . The inclusion criteria are individuals from both sexes, non-physically active (frequency of regular physical activity less than two sessions per week), no participation in any regular training program over the last 6 months preceding the beginning of the interventions; stage 1 or 2 hypertension (Stage $1=$ systolic blood pressure:
140 to $149 \mathrm{mmHg}$ or diastolic blood pressure: 90 to $99 \mathrm{mmHg}$; Stage 2 = systolic blood pressure 160 to $169 \mathrm{mmHg}$ or diastolic blood pressure: 100 to $109 \mathrm{mmHg})^{39}$; clinical evaluation by a physician (general physical examination, cardiological and clinical exercise testing) authorizing the practice of physical activity. The exclusion criteria are BMI $>35$; Coronary artery disease, insulin dependent diabetes mellitus; Chronic obstructive pulmonary disease; Osteoarticular disease that limits the practice of the training proposed; Peripheral vascular disease; smokers; medications that may interfere with physiological responses to tests, such as beta-blockers. All of the selected individuals will be invited to sign the informed consent approved 
by The Ethics Committee at University of Campinas (CAEE 54943216.7.0000.5404). The flow chart of the participant's selection is detailed in figure 3 .

The sample size was calculated using $\mathrm{G}^{*}$ Power 3.2.1 software, based on mean blood pressure (MBP) of a study with adults of middle age, before and after combined training ${ }^{31}$. Using a study design of an F test (ANOVA two way for repeated measurements), this analysis provided an $f$ effect size of 0.29 , with $\mathrm{p}<0.05$ and $95 \%$ power, yielding an $n$ of 14 in each group. The effect size of combined training observed in a previous study of our group ${ }^{40}$ of the secondary biomarker endpoints (glycemia, insulinemia, fat percentage, the interval between $\mathrm{R}$ waves, TNF- $\alpha, \mathrm{PCR}$, leptin, and adiponectin) were also calculated, resulting in less than the 28 individuals.

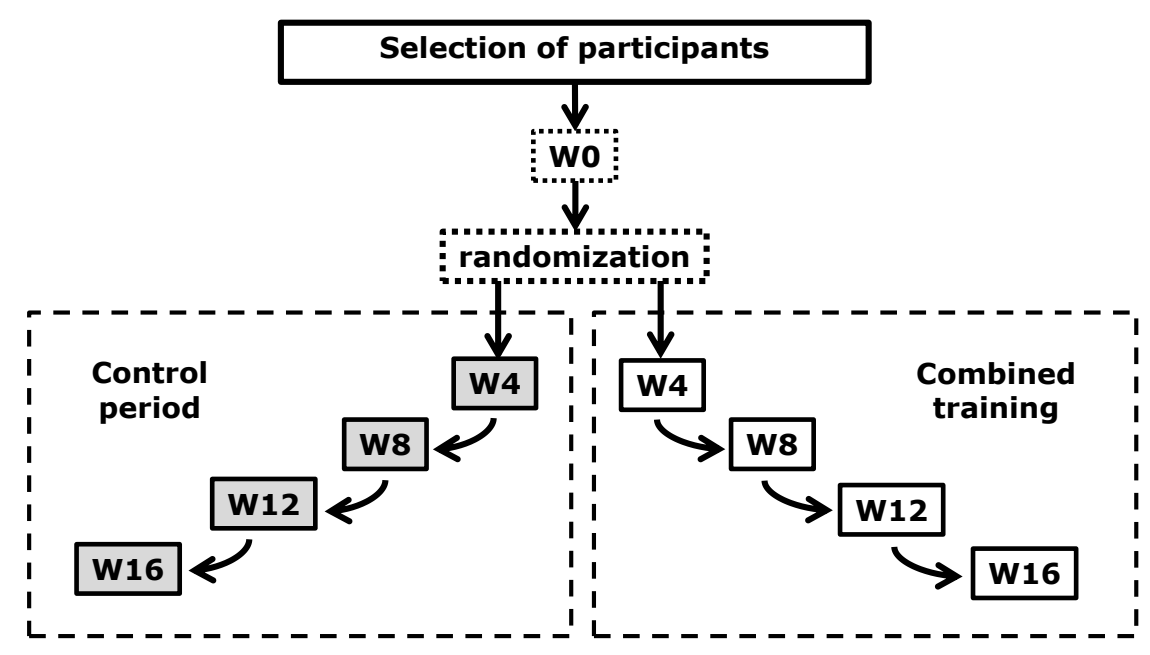

Figure 2. Experimental design. W: weeks of assessments; 0, 4, 8, 12 and 16 weeks along control and combined training period.

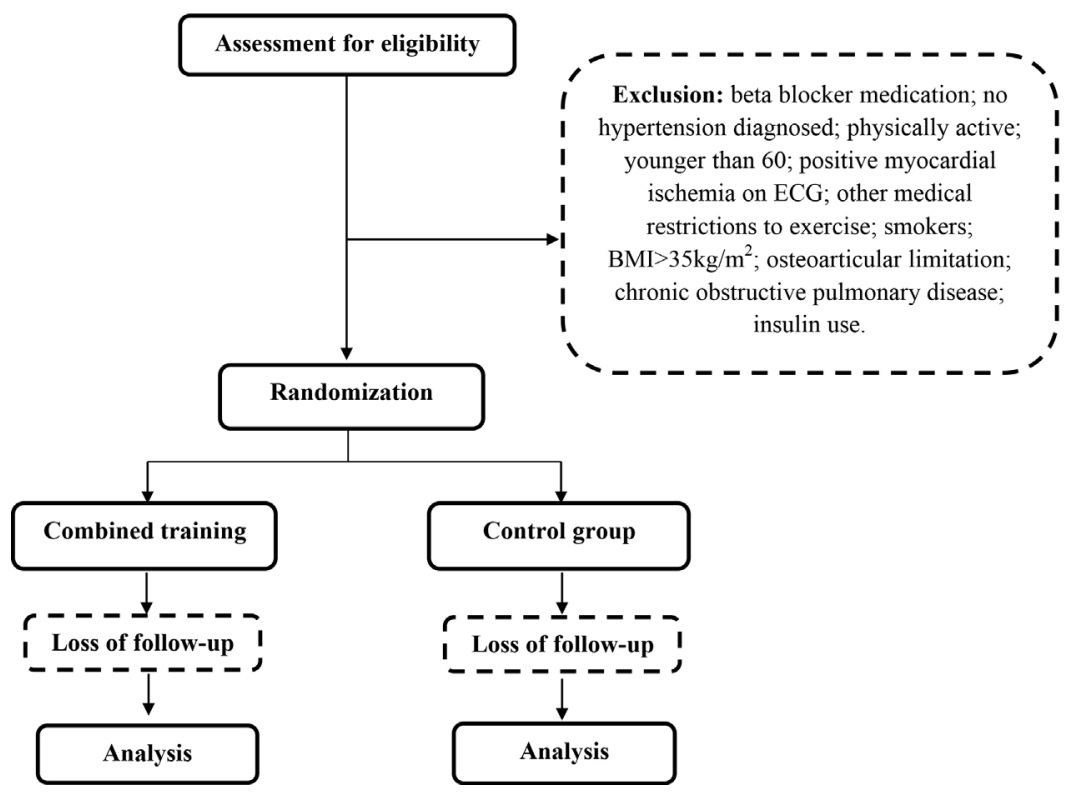

Figure 3. Flowchart of the participant's selection.

\section{Experimental design}

The participants of the present randomized clinical trial will be evaluated at baseline (W0), after 4 weeks (W4), after 8 weeks (W8), after 12 weeks (W12) and after 16 weeks (W16) of control or training intervention as described in Table 1.
After baseline assessments all participants will be allocated to two groups balanced by age, BMI, blood pressure and the mean interval between $\mathrm{R}$ waves, using a computerized random function. Each participant will be tested at the same time (between 7 am and $12 \mathrm{pm}$ ) along 16 weeks control or exercise training intervention. 
Table 1. Assessments details.

\begin{tabular}{|c|c|c|c|}
\hline Outcomes & Time & Methods & Description \\
\hline \multicolumn{4}{|l|}{ Physical fitness } \\
\hline Aerobic fitness & $\begin{array}{l}\text { W0/W8/ } \\
\text { W16 }\end{array}$ & $\begin{array}{l}\text { Maximal oxygen } \\
\text { consumption }\end{array}$ & $\begin{array}{l}\text { According to our previous work }{ }^{41} \text {, the subjects will perform a maximum-effort protocol } \\
\text { on the treadmill (a Quinton TM55, Bothell, WA), with breath-by-breath gas analysis } \\
\text { (CPX Medical Graphics, St.Paul, MN, USA). The ventilatory threshold, the respiratory } \\
\text { compensation point and the maximum oxygen consumption }\left(\mathrm{VO}_{2} \text { max) will be determined }\right. \\
\text { according to classical criteria }{ }^{42,43} \text {. }\end{array}$ \\
\hline $\begin{array}{l}\text { Muscle } \\
\text { strength }\end{array}$ & $\begin{array}{l}\text { W0/W8/ } \\
\text { W16 }\end{array}$ & $\begin{array}{l}\text { Lower limb dynamic } \\
\quad \text { isokinetic and } \\
\text { isometric strength; } \\
\text { and handgrip strength }\end{array}$ & $\begin{array}{l}\text { According to protocols previously described }{ }^{44} \text {, an isokinetic dynamometer (Biodex } \\
\text { System 4-Biomedical Systems, Newark, CA, USA), muscle strength will be assessed } \\
\text { through the peak torque for isometric strength of leg extension }{ }^{45} \text { and isokinetic strength } \\
\left(60^{\circ} / \mathrm{s}\right) \text { of concentric contractions of leg extension and flexion }{ }^{46} \text {, an angle of } 60^{\circ} \text { of flexion } \\
\left(0^{\circ}=\text { complete extension }\right)^{45} \text {. Handgrip strength will be quantified through a Jamar } \\
\text { dynamometer (Lafayette Instruments, Indiana, USA), positioned at the dominant hand of } \\
\text { each individual for three trials. For all tests, participants will be stimulated to use maximal } \\
\text { strength, as fast as possible and they will receive verbal encouragement }{ }^{47} \text {. }\end{array}$ \\
\hline Functional tests & $\begin{array}{l}\text { W0/ } \\
\text { W16 }\end{array}$ & $\begin{array}{l}\text { Sit and stand, TUG, sit } \\
\text { and reach, gait speed, } \\
\text { Berg's balance scale }\end{array}$ & $\begin{array}{l}\text { Functional mobility tests of Rikli and Jones will be assessed, including } 30 \text { seconds chair- } \\
\text { standing }{ }^{48} \text {, Timed Up and } \mathrm{Go}^{49} \text {, sit and reach test by Wells e Dillon }{ }^{50} \text {, gait speed along } \\
4.6 \text { meters }{ }^{51} \text {, Berg Scale for balance assessment }{ }^{52,53} \text {. }\end{array}$ \\
\hline $\begin{array}{c}\text { Physical } \\
\text { activity level }\end{array}$ & $\begin{array}{l}\text { W0/ } \\
\text { W16 }\end{array}$ & $\begin{array}{c}\text { Habitual Physical } \\
\text { Activity Questionnaire }\end{array}$ & $\begin{array}{l}\text { Physical activity level within a period of time will be assessed by an Likert type scale } \\
\text { which includes occupational activities, physical exercise and leisure activities based on } \\
\text { responses to } 16 \text { items }{ }^{54} \text {. }\end{array}$ \\
\hline \multicolumn{4}{|c|}{ Clinical outcomes } \\
\hline \multirow[t]{3}{*}{$\begin{array}{c}\text { Body } \\
\text { composition }\end{array}$} & $\begin{array}{l}\text { W0/W4/ } \\
\text { W8/ } \\
\text { W12/ } \\
\text { W16 }\end{array}$ & $\begin{array}{c}\text { Digital scale, } \\
\text { stadiometer, tape }\end{array}$ & $\begin{array}{l}\text { The weight will be measured by a calibrated scale (digital scale Filizola } \AA \text {, model ID1500) } \\
\text { to the nearest } 100 \mathrm{~g} \text {. Height will be measured to the nearest } 0.5 \mathrm{~cm} \text { using a stadiometer } \\
\text { (Digital Filizola } \AA \text { ). BMI will be calculated from these values (weight } / \text { height }^{2} \text { ). The } \\
\text { waist, hips and neck circumference will be measured by tape, as reliables markers of } \\
\text { cardiometabolic risk }{ }^{55-57} \text {. }\end{array}$ \\
\hline & & $\begin{array}{l}\text { Body } \\
\text { plethysmography }\end{array}$ & $\begin{array}{l}\text { Body volume will be measured through a densitometric technique (changes in air volumes } \\
\text { and internal pressure) at a plethysmograph chamber (BOD POD }{ }^{\circledR} \text { ) connected to a } \\
\text { software }{ }^{58} \text {. With body volume value, it is possible to estimate the lean and fat mass, using } \\
\text { the traditional Siri's equation }{ }^{59} \text {. }\end{array}$ \\
\hline & & $\begin{array}{l}\text { Ultrasound } \\
\text { muscle mass }\end{array}$ & $\begin{array}{l}\text { The thickness of biceps and vastus lateralis will be evaluated by ultrasound, according to } \\
\text { previously described protocols }{ }^{60,61} \text {. }\end{array}$ \\
\hline Blood pressure & $\begin{array}{l}\text { W0/W4/ } \\
\text { W8/ } \\
\text { W12/ } \\
\text { W16 }\end{array}$ & $\begin{array}{l}\text { Finger } \\
\text { photoplethysmography }\end{array}$ & $\begin{array}{l}\text { According to methods described in our previous study }{ }^{62} \text {, systolic, diastolic and mean } \\
\text { BP will be obtained using finger photoplethysmography, by Finometer Pro }{ }^{\circledR}(\text { Finapres } \\
\text { Medical System, Amsterdam, Holanda). The cuff is positioned at the distal phalanx of the } \\
\text { middle finger of the right upper limb }{ }^{63} \text {. The measure will be performed at rest conditions } \\
\text { according to American Heart Association's recommendations }{ }^{1} \text {, calculating the average of } \\
300 \text { beats at a stationary period in supine rest. }\end{array}$ \\
\hline Hemodynamics & $\begin{array}{l}\text { W0/W4/ } \\
\text { W8/ } \\
\text { W12/ } \\
\text { W16 }\end{array}$ & $\begin{array}{l}\text { Blood pressure } \\
\text { derived parameters }\end{array}$ & $\begin{array}{l}\text { Based on BP values and individual features the software of Finometer Proßalso estimates: } \\
\text { stroke volume as the true integrated mean of the simulated flow waveform between the } \\
\text { current upstroke and the dicrotic notch; pulse rate derived from the pulse interval; cardiac } \\
\text { output (stroke volume * heart rate); total systemic peripheral resistance as the ratio of } \\
\text { mean arterial pressure to cardiac output, assuming zero venous pressure (at the right } \\
\text { atrium); and baroreflex sensitivity as a cross-correlation function of blood pressure and } \\
\text { pulse interval }{ }^{64} \text {. }\end{array}$ \\
\hline $\begin{array}{l}\text { Vascular } \\
\text { autonomic } \\
\text { modulation }\end{array}$ & $\begin{array}{l}\text { W0/W4/ } \\
\text { W8/ } \\
\text { W12/ } \\
\text { W16 }\end{array}$ & $\begin{array}{l}\text { Blood pressure } \\
\text { variability }\end{array}$ & $\begin{array}{l}\text { Time and frequency domains of BP variability will be given by the software Cardio series } \\
\text { v } 2.4 \text {, using the data collected by Finometer Pro®(Finapres Medical System, Amsterdam, } \\
\text { Holanda) }{ }^{65} \text {. }\end{array}$ \\
\hline $\begin{array}{l}\text { Cardiac } \\
\text { autonomic } \\
\text { modulation }\end{array}$ & $\begin{array}{l}\text { W0/W4/ } \\
\text { W8/ } \\
\text { W12/ } \\
\text { W16 }\end{array}$ & Heart rate variability & $\begin{array}{l}\text { Continuous R-R intervals will be acquired in the same rest conditions of BP registration, } \\
\text { using a validated heart rate monitor (Polar RS } 800 \mathrm{CX} \text {, Kempele, Finland) }{ }^{66} \text {. We will } \\
\text { analyze heart rate variability (HRV) in both time and frequency domains }{ }^{13} \text {, during five } \\
\text { minutes stationary R-R intervals in Kubios HRV analysis software (MATLAB, version } 2 \\
\text { beta, Kuopio, Finland) }{ }^{67} \text {. }\end{array}$ \\
\hline $\begin{array}{l}\text { Peripheral } \\
\text { artery disease }\end{array}$ & $\begin{array}{l}\text { W0/W4/ } \\
\text { W8/ } \\
\text { W12/ } \\
\text { W16 }\end{array}$ & Brachial-ankle index & $\begin{array}{l}\text { It will be identified by the difference of systolic blood pressure of upper and lower limbs } \\
\text { (an indicator of atherosclerosis and peripheral arterial functionality) }{ }^{68-70} \text {. }\end{array}$ \\
\hline
\end{tabular}


Table 1. Continued

\begin{tabular}{|c|c|c|c|}
\hline Outcomes & Time & Methods & Description \\
\hline $\begin{array}{l}\text { Arterial } \\
\text { stiffness }\end{array}$ & $\begin{array}{l}\text { W0/W4/ } \\
\text { W8/ } \\
\text { W12/ } \\
\text { W16 }\end{array}$ & $\begin{array}{l}\text { Central and peripheral } \\
\text { pulse wave velocity } \\
\text { by applanation } \\
\text { tonometry }\end{array}$ & $\begin{array}{l}\text { Pulse wave velocity is obtained by SphygmoCor }{ }^{\circledR} \text { (AtCor Medical) according to } \\
\text { guidelines for clinical application of central and peripheral stiffness }{ }^{71} \text {. }\end{array}$ \\
\hline $\begin{array}{l}\text { Carotid arterial } \\
\text { compliance }\end{array}$ & $\begin{array}{l}\text { W0/W4/ } \\
\text { W8/ } \\
\text { W12/ } \\
\text { W16 }\end{array}$ & $\begin{array}{l}\text { Carotid diameter } \\
\text { by ultrasound with } \\
\text { simultaneously blood } \\
\text { pressure }\end{array}$ & $\begin{array}{l}\text { Images of the left carotid common artery diameter } 2 \mathrm{~cm} \text { under the carotid bifurcation } \\
\text { will be collected by ultrasound (Nanomaxxtm, SonoSite, EUA), acquired with the } \\
\text { linear transducer of } 10-5 \mathrm{MHz} \text {, at M mode, where a sequence of pictures for } 5 \text { seconds is } \\
\text { registered }{ }^{62} \text {. CC is calculated considering the difference between maximal and minimum } \\
\text { diameters along the } 5 \text { seconds pulse, associated with systolic and diastolic BP at the same } \\
\text { moment, gauged by a digital sphygmomanometer (Omron HEM-7113, Omron Corp, } \\
\text { Kyoto, Japan) }{ }^{62} \text {, according to the equation } \mathrm{CC}=([\mathrm{Sd}-\mathrm{Dd}] / \mathrm{Dd}) /(\mathrm{SBP}-\mathrm{DBP})^{62,72} \text {. }\end{array}$ \\
\hline $\begin{array}{l}\text { Arterial wall } \\
\text { thickness }\end{array}$ & $\begin{array}{l}\text { W0/W4/ } \\
\text { W8/ } \\
\text { W12/ } \\
\text { W16 }\end{array}$ & $\begin{array}{l}\text { Carotid intima- } \\
\text { media thickness by } \\
\text { ultrasound }\end{array}$ & $\begin{array}{l}\text { It will be registered by ultrasound image (Nanomaxxtm, SonoSite, EUA) acquired with } \\
\text { the linear transducer of } 10-5 \mathrm{MHz} \text {, from left carotid common artery } 2 \mathrm{~cm} \text { under the carotid } \\
\text { bifurcation and analyzed through the software image J (U.S. National Institutes of Health, } \\
\text { Bethesda, Maryland, USA) as described elsewhere }{ }^{73} \text {. }\end{array}$ \\
\hline $\begin{array}{l}\text { Endothelial } \\
\text { function }\end{array}$ & & $\begin{array}{l}\text { Flow-mediated } \\
\text { dilation }\end{array}$ & $\begin{array}{l}\text { The diameter of brachial artery will be measured through ultrasound (Nanomaxxtm, } \\
\text { SonoSite, EUA), acquired with the linear transducer of } 10-5 \mathrm{MHz} \text {, before and after } 5 \\
\text { minutes of occlusion in the forearm }(250 \mathrm{mmHg})^{74} \text {. The diameter will be recorded for } 30 \\
\text { seconds in the baseline condition (supine rest) and after } 30,60 \text { and } 90 \text { minutes of vascular } \\
\text { occlusion. }\end{array}$ \\
\hline $\begin{array}{l}\text { Metabolic } \\
\text { profile }\end{array}$ & $\begin{array}{l}\text { W0/W4/ } \\
\text { W8/ } \\
\text { W12/ } \\
\text { W16 }\end{array}$ & Blood analysis & $\begin{array}{l}\text { The blood samples will be obtained from the antecubital vein and collected into serum, } \\
\text { heparin- and EDTA-plasma Vacuette } \AA \text { tubes, after a minimum of } 12 \mathrm{~h} \text { fasting. Blood } \\
\text { sample will be centrifugated at } 3000 \mathrm{rpm} \text { for } 10 \mathrm{~min} \text {, separated in aliquots and stored at } \\
-80^{\circ} \mathrm{C} \text {. Glucose, total cholesterol, HDL, LDL, VLDL and triglycerides will be analyzed. }\end{array}$ \\
\hline $\begin{array}{l}\text { Systemic } \\
\text { Inflammatory } \\
\text { markers, } \\
\text { Growth factors, } \\
\text { Oxidative } \\
\text { stress and } \\
\text { tissue }\end{array}$ & $\begin{array}{l}\text { W0/ } \\
\text { W4/W8/ } \\
\text { W12/ } \\
\text { W16 }\end{array}$ & $\begin{array}{l}\text { Blood analysis in } \\
\text { ELISA }\end{array}$ & $\begin{array}{l}\text { The same samples mentioned above will be used to analysis of IL-6, IL-10, TNF- } \alpha \text {, CRP, } \\
\text { VEGF, BDNF, Antioxidant assay kit,TBARS, MMP-9, and TIMP-1 will be analysed in } \\
\text { duplicate by immunoenzymatic method ELISA (enzyme-linked immunosorbent assay, } \\
\text { ELISA, ELX } 800 \text { Biotek, USA model) by means of ultrasensitive kits (R \& D Systems) } \\
\text { using a specific kit for each of the markers. }\end{array}$ \\
\hline $\begin{array}{l}\text { Cognitive } \\
\text { functions }\end{array}$ & $\begin{array}{l}\text { W0 / } \\
\text { W16 }\end{array}$ & $\begin{array}{l}\text { Stroop test, MMSE, } \\
\text { ISLT, and GMLT. }\end{array}$ & $\begin{array}{l}\text { We will apply the computerized version of the Stroop test: TESTINPACS }{ }^{75} \text {. The } \\
\text { participants use the forefingers of both hands to press one of the two options of the } \\
\text { keyboard key ([ } \leftarrow] \text { or }[\rightarrow] \text { ). In step } 1 \text {, the participants have to choose the right name for } \\
\text { the color displayed on the screen. In step } 2 \text {, participants have to choose the right name } \\
\text { for the color writing displayed on the screen, with the letters colored always in white. } \\
\text { In step 3, participants have to choose the right name for the color of the word letters } \\
\text { instead the name of the color written. After receiving the instructions for the test, they will } \\
\text { perform one familiarization trial. The software registers the number of hits and the time } \\
\text { to answer in milliseconds. We will also apply the MMSE for sample characterization }{ }^{76} \\
\text { which evaluates the temporal orientation, spatial orientation, immediate memory, memory } \\
\text { recall, attention, calculation, and language }{ }^{77} \text {. It consists of a questionnaire, in which } \\
\text { the evaluator questions and proposes the tasks evaluated, adding points to successes. } \\
\text { Learning, executive function and memory will be evaluated by ISLT and GMLT and later } \\
\text { recall using the software Costate (Melbourn, VIC, Australia }{ }^{78} \text {. ISLT consists in a list of } \\
12 \text { words (e.g. Eggs, Orange, Toothpaste, etc.) verbally presented. The evaluator counts } \\
\text { the cumulative number of items recorded by the participant, along three trials. GMLT } \\
\text { evaluates the ability of the participant to learning the pathway along the } 10 x 10 \text { grid } \\
\text { through the total time needed to discover the way, the movements per second, number of } \\
\text { legal and illegal trials, according to the rules previous provided to the participant. After } \\
\text { the GMLT, the ISLT will be solicited again (later recall) to evaluate memory. }\end{array}$ \\
\hline Depression & $\begin{array}{l}\text { W0/ } \\
\text { W16 }\end{array}$ & GDS-15 & $\begin{array}{l}\text { The GDS- } 15 \text { is a short version of the original scale which is one of the most frequently } \\
\text { used tools for tracking depression in the elderly }{ }^{79} \text {. It is composed by } 15 \text { questions easy } \\
\text { to understand that avoid somatic complaints, detecting mood disorders and can be } \\
\text { administered by a trained interviewer. }\end{array}$ \\
\hline
\end{tabular}


Table 1. Continued

\begin{tabular}{|c|c|c|c|}
\hline Outcomes & Time & Methods & Description \\
\hline Renal function & $\begin{array}{c}\text { W0/W8/ } \\
\text { W16 }\end{array}$ & aMDRD & $\begin{array}{l}\text { The serum creatinine will be used as a marker of renal function, by applying two } \\
\text { equations set for estimation of glomerular filtration rate }{ }^{80} \text {. The equations are aMDRD } \\
\text { based on the serum creatinine variables, age, race and gender }{ }^{81} \text {, which applies best to the } \\
\text { elderly }{ }^{82} \text { and the formula of Cockroft-Gault (CKD-EPI) }{ }^{80,83} \text {. }\end{array}$ \\
\hline Quality of life & $\begin{array}{l}\text { W0/ } \\
\text { W16 }\end{array}$ & $\begin{array}{l}\text { WHOQOL-brief and } \\
\text { SF-36 questionnaire }\end{array}$ & $\begin{array}{l}\text { It is important to measure the quality of life (QOL), because the other assessments would } \\
\text { not identify the subjective portion of wellbeing and satisfaction of the elderly, essential to be } \\
\text { considered in a comprehensive health assessment. QOL will be assessed by WHOQOL-brief } \\
{ }^{84} \text {, in which QOL is divided into four domains: physical, psychological, social relationships } \\
\text { and environment. Furthermore, the assessment of QOL will be complemented by the SF-36 } \\
\text { questionnaire that is able to register the benefits of health-related QOL }{ }^{85} \text {. }\end{array}$ \\
\hline \multicolumn{4}{|l|}{ Monitoring } \\
\hline Medication & $\begin{array}{l}\text { W0/W4/ } \\
\text { W8/ } \\
\text { W12/ } \\
\text { W16 }\end{array}$ & $\begin{array}{l}\text { A detailed } \\
\text { questionnaire and } \\
\text { DDD }\end{array}$ & $\begin{array}{l}\text { Overall medication prescriptions by the clinicians of the patients will be required since the } \\
\text { first visit. The name, dosages, frequency and time of the day to take the medications will } \\
\text { be periodically checked. The assessment of medication changes, regarding the intensity of } \\
\text { therapy, will be quantified as the daily defined dose (DDD) through the method developed } \\
\text { by the World Health Organization }{ }^{86} \text {. }\end{array}$ \\
\hline Infection & $\begin{array}{l}\text { W0/W4/ } \\
\text { W8/ } \\
\text { W12/ } \\
\text { W16 }\end{array}$ & $\begin{array}{l}\text { WURSS- } 21 \text { and } \\
\text { DALDA }\end{array}$ & $\begin{array}{l}\text { Possible upper respiratory tract infections will be monitored through Wisconsin Upper } \\
\text { Respiratory Symptom Survey (WURSS-21) and Daily Analysis of Life Demands in } \\
\text { Athletes (DALDA) }{ }^{87} \text {, to differentiate this confounding factor of exercise training effects. }\end{array}$ \\
\hline Dietary intake & $\begin{array}{l}\text { W0/ } \\
\text { W16 }\end{array}$ & $\begin{array}{l}\text { Food frequency } \\
\text { questionnaire }\end{array}$ & $\begin{array}{l}\text { The Portuguese version of Food frequency questionnaire }{ }^{88} \text { will be applied to check } \\
\text { whether participants are changing the dietary intake along intervention. They will be } \\
\text { instructed to retain the same habits, mainly concerning about total caloric intake, sodium, } \\
\text { fat, oxidant and antioxidant aliments which directly affects the blood pressure. }\end{array}$ \\
\hline
\end{tabular}

Note: TUG: Time up and go; MLTPAQ: Minnesota Leisure Time Physical Activity Questionnaire; BMI: Body mass index; BP: Blood pressure; CC: Carotid compliance; SBP: Systolic blood pressure; DBP: Diastolic blood pressure; SD: Systolic diameter of the carotid artery; DD: Diastolic diameter of the carotid artery; HDL: High density lipoprotein; LDL: Low density lipoprotein; VLDL: very low density lipoprotein; IL-6: Interleukin 6; IL-10: Interleukin 10, TNF- $\alpha$ : Tumor necrosis factor alpha; CRP: C-reactive protein; VEGF: Vascular endothelial growth factor; BDNF: Brain-derived neurotrophic factor; TBARS: Thiobarbituric acid reactive substances; MMP-9: Matrix metalloproteinases 9; TIMP-1: Tissue inhibitor of metalloproteinase 1; ELISA: Enzyme-linked immunosorbent assay; MMSE: Mini mental exam test; ISLT: International Shopping List task; GMLT: Groton Maze Learning Test; GDS-15: Geriatric depression scale; aMDRD: abbreviated modification in diet in renal disease; WHOQOL brief: World health organization quality of life brief questionnaire; SF-36: Short Form Health Survey; QOL: Quality of life; DDD: daily defined dose; WURSS-21:Wisconsin Upper Respiratory Symptom Survey; DALDA: Daily Analysis of Life Demands in Athletes.

\section{Training Protocol}

Participants will be advised to maintain their normal diet and all their prescribed medications during the 16 weeks of intervention. The protocol of 16 weeks of combined training was based on exercise guidelines for hypertensive and elderly ${ }^{38,89}$. It is noteworthy the purpose of the minimum amount of resistance exercise recommended in these guidelines and a larger amount of aerobic exercise, due to the higher effectiveness from aerobic exercise on cardiovascular adaptations described in the literature ${ }^{21,27}$. The exercise sessions will be individually supervised. It will consist of seven resistance exercises for the major muscle groups followed by continuous walking and/or running twice per week and one additional session of only aerobic training, according to the prescription described in table 2. All training sessions will be held in the Integrated Laboratory of the Faculty of Physical Education, UNICAMP (LabFEF). Participants in the control group will not receive any treatment; however, they will monthly visit the research laboratory to make the same assessments which will be carried out for the training group.

\section{Statistical analysis}

Previously to the main analysis, data transformation should be held for non-normally distributed data. Mixed models for repeated measures should be applied for each variable considering the five-time points and two groups, followed by Bonferroni post hoc in case of significant interactions $(p<0.05)$. Complementary, the effect size of the adaptations at each time point will describe the magnitude of the difference between the combined training and control group, informing how long it does take to modify the organism of hypertensive elderly. Correlations and regressions between deltas will enable us to understand the cause-effect between adaptations along the time-course. Individual's responses may vary, justifying evaluation of responders and non-responders for key variables (such as blood pressure, autonomic cardiac modulation, body composition, cytokine concentrations and systemic oxidative stress markers). 


\section{Results}

The results of this study will provide a detailed description of the chronological sequence, every 4 weeks, of organic adaptations obtained during 16 weeks of combined training in the hypertensive elderly subjects, serving as a basis for future studies that aim to understand this complex relationship of the dynamics of the adaptations investigated.

Table 2. Combined training program.

\begin{tabular}{lcccc}
\hline & Type of exercise & Intensity & Volume & Frequency \\
\hline Resistance exercise & $\begin{array}{c}\text { leg extension and flexion, leg press, heel } \\
\text { lift, bench press, pulley, and abdominal }\end{array}$ & $\begin{array}{c}\text { RPE between 5-6 } \\
\text { (in a 10 point scale) }\end{array}$ & 1 set of 10-15 repetitions & twice per week \\
Endurance exercise & walking/running on treadmill and field & $46-63 \% \mathrm{VO}_{2}$ max. (speed) & 50 minutes continuous & three times per week \\
\hline
\end{tabular}

Note: RPE: ratio of perceived exertion; $\mathrm{VO}_{2}$ max: maximum oxygen consumption.

\section{Discussion}

Combined training by itself is able to reduce systolic and diastolic blood pressure of hypertensive subjects ${ }^{90}$, but due to the higher effectiveness of aerobic vs. resistance training ${ }^{91}$ we proposed a larger amount of aerobic exercise in the present program. The blood pressure reductions might arise, as a consequence of improvement in a variety of factors including sympathovagal balance, arterial function and structure, baroreflex sensitivity, systemic inflammation and weight control. Thus, in the next paragraphs, we are going to discuss how each of these adaptations is expected to develop along exercise training time-course.

The reduction in circulating blood glucose, advanced glycation end products (AGEs) and increase in insulin sensitivity could occur as a result of increased energy substrate utilization during exercise $\mathrm{e}^{92-94}$ and the up-regulation of auxiliary glucose uptake intracellular mechanisms, independent of insulin, by active muscles in every training session ${ }^{95}$. These changes might attenuate oxidative stress, vascular tissue damage, and an increase in nitric oxide biodisponibility ${ }^{96,97}$ which added to increase in endothelial vascular shear stress (increased blood flow during exercise) would improve endothelial function and vasodilation, leading in turns to arterial compliance and baroreflex sensitivity improvements ${ }^{18,29,98}$. These changes may precede the increase in parasympathetic modulation and the reduction of sympathetic modulation to the heart and vessels, respectively $18,34,57,99,100$. Improvements in cardiovascular autonomic modulation could also be induced by neuronal protection against potential glucose neurotoxicity ${ }^{101}$.

Body fat reduction is progressive during the training program due to the increase in energy expenditure during and after each training session. That is associated with an increased mitochondrial biogenesis which occurs in skeletal muscle and other tissues ${ }^{55,98}$, increased metabolic rate re, $102^{94}$ and fat oxidation ${ }^{103,104}$. The fat reduction, together with the improvement in glucose uptake, reduced the concentration of the final advanced glycation end products and proinflammatory markers, in turns improving insulin sensitivity. Nevertheless, the training protocol proposed herein may not induce substantial fat reduction, enough to influence beneficial adaptations through this pathway.
The overload on muscle fibers induces muscle damage following each exercise session and may increase the concentration of inflammation and reactive oxygen species at the beginning of the training period ${ }^{105,106}$. After several weeks of exercise training there is an expected reduction of reactive oxygen species (initially high) and increase in the antioxidant capacity ${ }^{106}$, ${ }^{107}$, which might also culminate in blood pressure reduction by the mediation of reduced $\mathrm{T}$ cell activation response to angiotensin II, and vascular endothelial function improvement ${ }^{108,} 109$.

The cardiovascular autonomic modulation adaptations contribute directly to the reduction of heart rate and blood pressure at rest $^{18}$. Cardiovascular autonomic modulation adaptations may reduce systemic inflammation in different ways: by increasing parasympathetic modulation and thereby inhibit TNF- $\alpha$ production by splenic macrophages primarily ${ }^{16}$, ${ }^{110}$; reducing the secretion of free fatty acids (lipolysis reduction) by decreasing sympathetic hyperactivity for the adipocytes, and by stimulating the hypothalamic-pituitary-adrenal axis to increase the production of glucocorticoids, thereby inhibiting the production of proinflammatory cytokines ${ }^{106}$. A reduction in body fat would further reduce the amount of macrophages M1 and increase macrophages M2 to adipose tissue, which enhances the regulatory $\mathrm{T}$ cell activity and reduces the expression of tolllike receptors, stimulating reduction of TNF- $\alpha$ production, IL - 6 and increasing IL-10 and adiponectin production ${ }^{20,40,111}$. Other mechanisms that stimulate the pro-inflammatory reduction, are the signaling cascades triggered by muscular IL-6 every exercise session, which in turn stimulates monocytes and macrophages to reduce TNF- $\alpha$ production and increase IL10 production, respectively ${ }^{20}$. The reduction of body fat with exercise training and reduced pro-inflammatory markers may also reduce C-reactive protein production by the liver. Possibly, these inflammatory changes accentuate or contribute to the maintenance of the expected blood pressure reduction and reduce cardiovascular risk by several other means after the training period $^{20,35,109}$.

There are also two other important adaptations induced by aerobic and resistance training for the elderly. First, the increase in maximum oxygen consumption which is an independent predictor of mortality ${ }^{112}$, may be obtained after at least 8 weeks training by the increase in arteriovenous oxygen difference and especially by the increase in cardiac output (by myocardial 
contraction force increase, end-diastolic volume increase and improvements in autonomic control efficiency) $)^{113}$. Second, an increase in muscle mass is important for good health, functional independence and falls avoidance in age $\mathrm{e}^{38,114,115}$. These changes may occur even at the beginning of the intervention ${ }^{61,103,116}$.

Furthermore, we expect improvements in cognitive function, functional performance, and quality of life ${ }^{117-119}$. These complementary benefits might be related to the cardiovascular functions improvements, metabolism, strength, aerobic fitness and also psychological and social effects that emerge from exercise training intervention ${ }^{104,120-123}$.

In summary, this study will open the way towards the chased understanding of the relationship between autonomic and immune system exercise-induced adaptations, especially regarding their effects on blood pressure. Furthermore, the follow up of diverse organic adaptations along exercise training stimulus will contribute to the understanding of the complex relationship among organic structures and functions, describing a comprehensive time-course analysis of elderly healthy and quality of life.

\section{References}

1. Perloff D, Grim C, Flack J, Frohlich ED, Hill M, McDonald M, et al. Human blood pressure determination by sphygmomanometry. Circulation. 1993;88(5 Pt 1):2460-70.

2. WHO. Global Brief on Hypertension: Silent killer, global public health crisis. Switzerland: 2013.

3. Writing Group M, Mozaffarian D, Benjamin EJ, Go AS, Arnett DK, Blaha MJ, et al. Heart Disease and Stroke Statistics-2016 Update: A Report From the American Heart Association. Circulation. 2016;133(4):e38-360.

4. Secretaria de Vigilância em Saúde (SVS): Vigilância de fatores de risco e proteção para doenças crônicas por inquérito telefônico (VIGITEL) [Internet]. 2010. Available from: http://tabnet.datasus. gov.br/cgi/tabnet.exe?idb2010/g02.def.

5. McCarthy CG, Goulopoulou S, Wenceslau CF, Spitler K, Matsumoto T, Webb RC. Toll-like receptors and damage-associated molecular patterns: novel links between inflammation and hypertension. American journal of physiology Heart and circulatory physiology. 2014;306(2):H184-96.

6. Brook RD, Appel LJ, Rubenfire M, Ogedegbe G, Bisognano JD, Elliott WJ, et al. Beyond medications and diet: alternative approaches to lowering blood pressure: a scientific statement from the american heart association. Hypertension. 2013;61(6):1360-83.

7. Bruunsgaard H, Pedersen BK. Age-related inflammatory cytokines and disease. Immunol Allergy Clin North Am. 2003;23(1):15-39.

8. Franceschi C, Capri M, Monti D, Giunta S, Olivieri F, Sevini F, et al. Inflammaging and anti-inflammaging: a systemic perspective on aging and longevity emerged from studies in humans. Mech Ageing Dev. 2007;128(1):92-105.

9. Migliaro ER, Contreras P, Bech S, Etxagibel A, Castro M, Ricca $\mathrm{R}$, et al. Relative influence of age, resting heart rate and sedentary life style in short-term analysis of heart rate variability. Braz J Med Biol Res. 2001;34(4):493-500.
10. Wichi RB, De Angelis K, Jones L, Irigoyen MC. A brief review of chronic exercise intervention to prevent autonomic nervous system changes during the aging process. Clinics (Sao Paulo). 2009;64(3):253-8.

11. Ferrucci L, Penninx BW, Volpato S, Harris TB, Bandeen-Roche $\mathrm{K}$, Balfour J, et al. Change in muscle strength explains accelerated decline of physical function in older women with high interleukin-6 serum levels. J Am Geriatr Soc. 2002;50(12):1947-54.

12. Bruunsgaard H, Andersen-Ranberg K, Hjelmborg J, Pedersen BK, Jeune B. Elevated levels of tumor necrosis factor alpha and mortality in centenarians. Am J Med. 2003;115(4):278-83.

13. TFotESo. Heart rate variability. Standards of measurement, physiological interpretation, and clinical use. Task Force of the European Society of Cardiology and the North American Society of Pacing and Electrophysiology. Eur Heart J. 1996;17(3):354-81.

14. Schwartz PJ. The autonomic Nervous System and Sudden death. Eur Heart J. 1998;19:72-80.

15. Madden KS, Felten DL. Experimental basis for neural-immune interactions. Physiol Rev. 1995;75(1):77-106.

16. Tracey KJ. The inflammatory reflex. Nature. 2002;420(6917):853-9.

17. Masson GS, Nair AR, Silva Soares PP, Michelini LC, Francis J. Aerobic training normalizes autonomic dysfunction, HMGB1 content, microglia activation and inflammation in hypothalamic paraventricular nucleus of SHR. American journal of physiology Heart and circulatory physiology. 2015;309(7):H1115-22.

18. Masson GS, Costa TS, Yshii L, Fernandes DC, Soares PP, Laurindo FR, et al. Time-dependent effects of training on cardiovascular control in spontaneously hypertensive rats: role for brain oxidative stress and inflammation and baroreflex sensitivity. PLoS One. 2014;9(5):e94927.

19. Cardinale JP, Sriramula S, Mariappan N, Agarwal D, Francis $\mathrm{J}$. Angiotensin II-induced hypertension is modulated by nuclear factor-kappaBin the paraventricular nucleus. Hypertension. 2012;59(1):113-21.

20. Gleeson M, Bishop NC, Stensel DJ, Lindley MR, Mastana SS, Nimmo MA. The anti-inflammatory effects of exercise: mechanisms and implications for the prevention and treatment of disease. Nat Rev Immunol. 2011;11(9):607-15.

21. Cornelissen VA, Smart NA. Exercise training for blood pressure: a systematic review and meta-analysis. J Am Heart Assoc. 2013;2(1):e004473.

22. Donges CE, Duffield R, Drinkwater EJ. Effects of resistance or aerobic exercise training on interleukin-6, C-reactive protein, and body composition. Medicine and science in sports and exercise. 2010;42(2):304-13.

23. Martins-Pinge MC. Cardiovascular and autonomic modulation by the central nervous system after aerobic exercise training. Braz J Med Biol Res. 2011;44(9):848-54.

24. Carter JB, Banister EW, Blaber AP. Effect of endurance exercise on autonomic control of heart rate. Sports Med. 2003;33(1):33-46.

25. Taylor AC, McCartney N, Kamath MV, Wiley RL. Isometric training lowers resting blood pressure and modulates autonomic control. Medicine and science in sports and exercise. 2003;35(2):251-6.

26. Nualnim N, Barnes JN, Tarumi T, Renzi CP, Tanaka H. Comparison of central artery elasticity in swimmers, runners, and the sedentary. Am J Cardiol. 2011;107(5):783-7. 
27. Sardeli AV, Gáspari AF, Chacon-Mikahil MPT. Acute, short and long-term effects of different types of exercise in central arterial stiffness: a systematic review and meta-analysis. Journal of sports medicine and physical fitness. 2018;58(6).

28. Collier SR, Frechette V, Sandberg K, Schafer P, Ji H, Smulyan H, et al. Sex differences in resting hemodynamics and arterial stiffness following 4 weeks of resistance versus aerobic exercise training in individuals with pre-hypertension to stage 1 hypertension. Biol Sex Differ. 2011;2(1):9.

29. Collier SR, Kanaley JA, Carhart R, Jr., Frechette V, Tobin MM, Hall AK, et al. Effect of 4 weeks of aerobic or resistance exercise training on arterial stiffness, blood flow and blood pressure in preand stage-1 hypertensives. J Hum Hypertens. 2008;22(10):678-86.

30. Newcomer SC, Thijssen DH, Green DJ. Effects of exercise on endothelium and endothelium/smooth muscle cross talk: role of exercise-induced hemodynamics. Journal of applied physiology. 2011;111(1):311-20.

31. Laterza MC, de Matos LD, Trombetta IC, Braga AM, Roveda $\mathrm{F}$, Alves MJ, et al. Exercise training restores baroreflex sensitivity in never-treated hypertensive patients. Hypertension. 2007;49(6):1298-306.

32. Guimaraes GV, Ciolac EG, Carvalho VO, D'Avila VM, Bortolotto LA, Bocchi EA. Effects of continuous vs. interval exercise training on blood pressure and arterial stiffness in treated hypertension. Hypertens Res. 2010;33(6):627-32.

33. Figueroa A, Park SY, Seo DY, Sanchez-Gonzalez MA, Baek YH. Combined resistance and endurance exercise training improves arterial stiffness, blood pressure, and muscle strength in postmenopausal women. Menopause. 2011;18(9):980-4.

34. Soares-Miranda L, Sandercock G, Vale S, Santos R, Abreu S, Moreira C, et al. Metabolic syndrome, physical activity and cardiac autonomic function. Diabetes Metab Res Rev. 2012;28(4):363-9.

35. Wanderley FA, Moreira A, Sokhatska O, Palmares C, Moreira P, Sandercock G, et al. Differential responses of adiposity, inflammation and autonomic function to aerobic versus resistance training in older adults. Experimental gerontology. 2013;48(3):326-33.

36. Page IH. Theories concerning causes of hypertension. Hypertension Research: a memoi 1920-1960. 1.ed.: Pergamon Press; 1989. p. 56-61.

37. Freitas EV, Py L, Cançado FAX, Doll J, Gorzoni ML. Tratado de geriatria e gerontologia. 3 ed ed. Rio de Janeiro: Guanabara Kogan; 2011.

38. Chodzko-Zajko WJ, Proctor DN, Fiatarone Singh MA, Minson CT, Nigg CR, Salem GJ, et al. American College of Sports Medicine position stand. Exercise and physical activity for older adults. Medicine and science in sports and exercise. 2009;41(7):1510-30.

39. Chobanian AV, Bakris GL, Black HR, Cushman WC, Green LA, Izzo JL, Jr., et al. The Seventh Report of the Joint National Committee on Prevention, Detection, Evaluation, and Treatment of High Blood Pressure: the JNC 7 report. JAMA. 2003;289(19):2560-72.

40. Brunelli DT, Caram K, Nogueira FR, Libardi CA, Prestes J, Cavaglieri CR. Immune responses to an upper body tri-set resistance training session. Clin Physiol Funct Imaging. 2014;34(1):64-71.

41. Libardi CA, De Souza GV, Cavaglieri CR, Madruga VA, ChaconMikahil MP. Effect of resistance, endurance, and concurrent training on TNF-alpha, IL-6, and CRP. Medicine and science in sports and exercise. 2012;44(1):50-6.
42. Heubert RA, Billat VL, Chassaing P, Bocquet V, Morton RH, Koralsztein JP, et al. Effect of a previous sprint on the parameters of the work-time to exhaustion relationship in high intensity cycling. International journal of sports medicine. 2005;26(7):583-92.

43. Howley ET, Bassett DR, Jr., Welch HG. Criteria for maximal oxygen uptake: review and commentary. Medicine and science in sports and exercise. 1995;27(9):1292-301.

44. Libardi CA, Souza TM, Conceicao MS, Bonganha V, ChaconMikahil MP, Cavaglieri CR, et al. Electromechanical delay of the knee extensor muscles: comparison among young, middle-age and older individuals. Clin Physiol Funct Imaging. 2015;35(4):245-9.

45. Wallerstein LF, Barroso R, Tricoli V, Mello MT, Ugrinowitsch C. The influence of familiarization sessions on the stability of ramp and ballistic isometric torque in older adults. J Aging Phys Act. 2010;18(4):390-400.

46. Hartmann A, Knols R, Murer K, de Bruin ED. Reproducibility of an isokinetic strength-testing protocol of the knee and ankle in older adults. Gerontology. 2009;55(3):259-68.

47. Symons TB, Vandervoort AA, Rice CL, Overend TJ, Marsh GD. Reliability of a single-session isokinetic and isometric strength measurement protocol in older men. J Gerontol A Biol Sci Med Sci. 2005;60(1):114-9.

48. Jones CJ, Rikli RE, Beam WC. A 30-s chair-stand test as a measure of lower body strength in community-residing older adults. Res Q Exerc Sport. 1999;70(2):113-9.

49. Podsiadlo D, Richardson S. The timed "Up \& Go": a test of basic functional mobility for frail elderly persons. J Am Geriatr Soc. 1991;39(2):142-8.

50. Wells KF, Dillon EK. The sit and reach: a test of back and leg flexibility. Research Quarterly for Exercise and Sport. 1952;23:115-8.

51. Guralnik JM, Simonsick EM, Ferrucci L, Glynn RJ, Berkman LF, Blazer DG, et al. A short physical performance battery assessing lower extremity function: association with self-reported disability and prediction of mortality and nursing home admission. J Gerontol. 1994;49(2):M85-94.

52. Miyamoto ST, Lombardi Junior I, Berg KO, Ramos LR, Natour J. Brazilian version of the Berg balance scale. Braz J Med Biol Res. 2004;37(9):1411-21.

53. Berg K, Norman KE. Functional assessment of balance and gait. Clin Geriatr Med. 1996;12(4):705-23.

54. Florindo AA, Latorre Mdo R, Jaime PC, Tanaka T, Zerbini CA. [Methodology to evaluation the habitual physical activity in men aged 50 years or more]. Rev Saude Publica. 2004;38(2):307-14.

55. Sutherland LN, Bomhof MR, Capozzi LC, Basaraba SA, Wright DC. Exercise and adrenaline increase PGC-1 \{alpha\} mRNA expression in rat adipose tissue. J Physiol. 2009;587(Pt 7):1607-17.

56. Shoelson SE, Lee J, Goldfine AB. Inflammation and insulin resistance. J Clin Invest. 2006;116(7):1793-801.

57. Singh JP, Larson MG, O’Donnell CJ, Wilson PF, Tsuji H, LloydJones DM, et al. Association of hyperglycemia with reduced heart rate variability (The Framingham Heart Study). Am J Cardiol. 2000;86(3):309-12.

58. Guedes DP, Guedes JERP. Manual Prático para Avaliação em Educação Física: Manole; 2006.

59. Siri WE. body composition from fluid spaces and density: analysis of methods. Techniques for mensuring body composition: National academy of Sciences; 1961. p. 223-4. 
60. Abe T, Kondo M, Kawakami Y, Fukunaga T. Prediction Equations for Body Composition of Japanese Adults by B-mode Ultrasound. American Journal of Human Biology. 1994;6:161-70.

61. Abe T, DeHoyos DV, Pollock ML, Garzarella L. Time course for strength and muscle thickness changes following upper and lower body resistance training in men and women. European journal of applied physiology. 2000;81(3):174-80.

62. Sardeli AV, Santos LC, Ferreira MLV, Gáspari AF, Rodrigues B, Cavaglieri CR, et al. Cardiovascular responses to different resistance exercise protocols in elderly. International journal of sports medicine. 2017;38:928-36.

63. Guelen I, Westerhof BE, van der Sar GL, van Montfrans GA, Kiemeneij F, Wesseling KH, et al. Validation of brachial artery pressure reconstruction from finger arterial pressure. J Hypertens. 2008;26(7):1321-7.

64. FMS. Finometer User's Guide. Amsterdam: Finapres Medical Systems BV. Amsterdam2005. p. 221.

65. Parati G, Frattola A, Di Rienzo M, Mancia G. Blood pressure variability. Importance in research and in clinical hypertension. Arq Bras Cardiol. 1996;67(2):131-3.

66. Hernando D, Garatachea N, Almeida R, Casajus JA, Bailon R. Validation of heart rate monitor Polar RS 800 for heart rate variability analysis during exercise. Journal of strength and conditioning research. 2016:ahead of print.

67. Niskanen JP, Tarvainen MP, Ranta-Aho PO, Karjalainen PA. Software for advanced HRV analysis. Comput Methods Programs Biomed. 2004;76(1):73-81.

68. Ankle Brachial Index C, Fowkes FG, Murray GD, Butcher I, Heald CL, Lee RJ, et al. Ankle brachial index combined with Framingham Risk Score to predict cardiovascular events and mortality: a meta-analysis. JAMA. 2008;300(2):197-208.

69. Rooke TW, Hirsch AT, Misra S, Sidawy AN, Beckman JA, Findeiss LK, et al. 2011 ACCF/AHA Focused Update of the Guideline for the Management of Patients With Peripheral Artery Disease (updating the 2005 guideline): a report of the American College of Cardiology Foundation/American Heart Association Task Force on Practice Guidelines. J Am Coll Cardiol. 2011;58(19):2020-45.

70. Aboyans V, Criqui MH, Abraham P, Allison MA, Creager MA, Diehm C, et al. Measurement and interpretation of the ankle-brachial index: a scientific statement from the American Heart Association. Circulation. 2012;126(24):2890-909.

71. Van Bortel LM, Duprez D, Starmans-Kool MJ, Safar ME, Giannattasio C, Cockcroft J, et al. Clinical applications of arterial stiffness, Task Force III: recommendations for user procedures. Am J Hypertens. 2002;15(5):445-52.

72. Juonala M, Järvisalo MJ, Mäki-Torkko N, Kähönen M, Viikari JSA, Raitakari OT. Risk Factors Identified in Childhood and Decreased Carotid Artery Elasticity in Adulthood The Cardiovascular Risk in Young Finns Study. Circulation. 2005;112:1486-93.

73. Ferreira-Sae MC, Cipolli JA, Cornelio ME, Matos-Souza JR, Fernandes MN, Schreiber R, et al. Sodium intake is associated with carotid artery structure alterations and plasma matrix metalloproteinase-9 upregulation in hypertensive adults. J Nutr. 2011;141(5):877-82.

74. Rodriguez-Miguelez P, Seigler N, Harris RA. Ultrasound Assessment of Endothelial Function: A Technical Guideline of the Flow-mediated Dilation Test. J Vis Exp. 2016(110).
75. Stroop JR. Studies of interference in serial verbal reaction. Journal of Experimental Psychology. 1935;18(6):643-62.

76. Folstein MF, Folstein SE, McHugh PR. "Mini-mental state". A practical method for grading the cognitive state of patients for the clinician. J Psychiatr Res. 1975;12(3):189-98.

77. Bertolucci PH, Brucki SM, Campacci SR, Juliano Y. [The MiniMental State Examination in a general population: impact of educational status]. Arq Neuropsiquiatr. 1994;52(1):1-7.

78. Shah T, Verdile G, Sohrabi H, Campbell A, Putland E, Cheetham $\mathrm{C}$, et al. A combination of physical activity and computerized brain training improves verbal memory and increases cerebral glucose metabolism in the elderly. Transl Psychiatry. 2014;4:e487.

79. Paradela EM, Lourenco RA, Veras RP. [Validation of geriatric depression scale in a general outpatient clinic]. Rev Saude Publica. 2005;39(6):918-23.

80. Fliser D. Assessment of renal function in elderly patients. Curr Opin Nephrol Hypertens. 2008;17(6):604-8.

81. Levey AS, Coresh J, Balk E, Kausz AT, Levin A, Steffes MW, et al. National Kidney Foundation practice guidelines for chronic kidney disease: evaluation, classification, and stratification. Ann Intern Med. 2003;139(2):137-47.

82. Verhave JC, Fesler P, Ribstein J, du Cailar G, Mimran A. Estimation of renal function in subjects with normal serum creatinine levels: influence of age and body mass index. Am J Kidney Dis. 2005;46(2):233-41.

83. Earley A, Miskulin D, Lamb EJ, Levey AS, Uhlig K. Estimating equations for glomerular filtration rate in the era of creatinine standardization: a systematic review. Ann Intern Med. 2012;156(11):785-95, W-270, W-1, W-2, W-3, W-4, W-5, W-6, W-7, W-8.

84. Silva PAB, Soares SM, Santos JFG, Silva LB. Cut-off point for WHOQOL-bref as a measure of quality of life of older adults. Revista de Saúde Publica. 2014;48(3):390-7.

85. Ciconelli RM, Ferraz MB, Santos W, Meinão I, Quaresma MR. Translation into Portuguese and validation of the generic questionnaire for assessing quality of life SF- 36. Rev Bras Reumatol. 1999;39:143-50.

86. WHO. ATC classification index with DDDs 2017. In: Methodology CCfDS, editor.; Oslo, Norway2016.

87. Moreira A, Cavazzoni PB. Monitorando o treinamento através do Wisconsin Upper Respiratory Symptom Survey-21 e Daily Analysis of Life Demands in Athletes nas versões em língua portuguesa. $\mathrm{R}$ da Educação Física/UEM. 2009;20(1):109-19.

88. Pedraza DF, Menezes TN. Questionários de Frequência de Consumo Alimentar desenvolvidos e validados para população do Brasil: revisão da literatura. Revista Ciência \& Saúde Coletiva. 2015;20(9):2697-720.

89. Pescatello LS, Franklin BA, Fagard R, Farquhar WB, Kelley GA, Ray CA, et al. American College of Sports Medicine position stand. Exercise and hypertension. Medicine and science in sports and exercise. 2004;36(3):533-53.

90. Corso LM, Macdonald HV, Johnson BT, Farinatti P, Livingston J, Zaleski AL, et al. Is Concurrent Training Efficacious Antihypertensive Therapy? A Meta-analysis. Medicine and science in sports and exercise. 2016;48(12):2398-406. 
91. Cornelissen VA, Buys R, Smart NA. Endurance exercise beneficially affects ambulatory blood pressure: a systematic review and meta-analysis. J Hypertens. 2013;31(4):639-48.

92. Campbell PT, Campbell KL, Wener MH, Wood BL, Potter JD, McTiernan A, et al. A yearlong exercise intervention decreases CRP among obese postmenopausal women. Medicine and science in sports and exercise. 2009;41(8):1533-9.

93. Mikus CR, Oberlin DJ, Libla J, Boyle LJ, Thyfault JP. Glycaemic control is improved by 7 days of aerobic exercise training in patients with type 2 diabetes. Diabetologia. 2012;55(5):1417-23.

94. Campbell WW, Crim MC, Young VR, Evans WJ. Increased energy requirements and changes in body composition with resistance training in older adults. Am J Clin Nutr. 1994;60(2):167-75.

95. Goodyear LJ, Kahn BB. Exercise, glucose transport, and insulin sensitivity. Annu Rev Med. 1998;49:235-61.

96. Singleton JR, Smith AG, Russell JW, Feldman EL. Microvascular complications of impaired glucose tolerance. Diabetes. 2003;52(12):2867-73.

97. Panzer C, Lauer MS, Brieke A, Blackstone E, Hoogwerf B. Association of fasting plasma glucose with heart rate recovery in healthy adults: a population-based study. Diabetes. 2002;51(3):803-7.

98. Monahan KD, Tanaka H, Dinenno FA, Seals DR. Central arterial compliance is associated with age- and habitual exercise-related differences in cardiovagal baroreflex sensitivity. Circulation. 2001;104(14):1627-32.

99. Collier SR, Kanaley JA, Carhart R, Jr., Frechette V, Tobin MM, Bennett $\mathrm{N}$, et al. Cardiac autonomic function and baroreflex changes following 4 weeks of resistance versus aerobic training in individuals with pre-hypertension. Acta Physiol (Oxf). 2009;195(3):339-48.

100. Catai AM, Chacon-Mikahil MP, Martinelli FS, Forti VA, Silva E, Golfetti R, et al. Effects of aerobic exercise training on heart rate variability during wakefulness and sleep and cardiorespiratory responses of young and middle-aged healthy men. Braz J Med Biol Res. 2002;35(6):741-52.

101. Dimova R, Tankova T, Guergueltcheva V, Tournev I, Chakarova $\mathrm{N}$, Grozeva $\mathrm{G}$, et al. Risk factors for autonomic and somatic nerve dysfunction in different stages of glucose tolerance. J Diabetes Complications. 2016.

102. Mole PA. Impact of energy intake and exercise on resting metabolic rate. Sports Med. 1990;10(2):72-87.

103. Cadore EL, Izquierdo M, Pinto SS, Alberton CL, Pinto RS, Baroni $\mathrm{BM}$, et al. Neuromuscular adaptations to concurrent training in the elderly: effects of intrasession exercise sequence. Age (Dordr). 2013;35(3):891-903.

104. Hawley JA, Hargreaves M, Joyner MJ, Zierath JR. Integrative biology of exercise. Cell. 2014;159(4):738-49.

105. Allen DG, Whitehead NP, Yeung EW. Mechanisms of stretch-induced muscle damage in normal and dystrophic muscle: role of ionic changes. J Physiol. 2005;567(Pt 3):723-35.

106. Sallam N, Laher I. Exercise Modulates Oxidative Stress and Inflammation in Aging and Cardiovascular Diseases. Oxid Med Cell Longev. 2016;2016:7239639.

107. Walsh NP, Gleeson M, Shephard RJ, Gleeson M, Woods JA, Bishop NC, et al. Position statement. Part one: Immune function and exercise. Exerc Immunol Rev. 2011;17:6-63.
108. Guzik TJ, Hoch NE, Brown KA, McCann LA, Rahman A, Dikalov $\mathrm{S}$, et al. Role of the $\mathrm{T}$ cell in the genesis of angiotensin II induced hypertension and vascular dysfunction. J Exp Med. 2007;204(10):2449-60.

109. Harrison DG. The immune system in hypertension. Trans Am Clin Climatol Assoc. 2014;125:130-38; discussion 8-40.

110. Tentolouris N, Argyrakopoulou G, Katsilambros N. Perturbed autonomic nervous system function in metabolic syndrome. Neuromolecular Med. 2008;10(3):169-78.

111. Ploeger HE, Takken T, de Greef MH, Timmons BW. The effects of acute and chronic exercise on inflammatory markers in children and adults with a chronic inflammatory disease: a systematic review. Exerc Immunol Rev. 2009;15:6-41.

112. Kodama S, Saito K, Tanaka S, Maki M, Yachi Y, Asumi M, et al. Cardiorespiratory fitness as a quantitative predictor of all-cause mortality and cardiovascular events in healthy men and women: a meta-analysis. JAMA. 2009;301(19):2024-35.

113. Jones AM, Carter H. The effect of endurance training on parameters of aerobic fitness. Sports Med. 2000;29(6):373-86.

114. Ishigaki EY, Ramos LG, Carvalho ES, Lunardi AC. Effectiveness of muscle strengthening and description of protocols for preventing falls in the elderly: a systematic review. Braz J Phys Ther. 2014;18(2):111-8.

115. Reid KF, Naumova EN, Carabello RJ, Phillips EM, Fielding RA. Lower extremity muscle mass predicts functional performance in mobility-limited elders. J Nutr Health Aging. 2008;12(7):493-8.

116. Scanlon TC, Fragala MS, Stout JR, Emerson NS, Beyer KS, Oliveira LP, et al. Muscle architecture and strength: adaptations to short-term resistance training in older adults. Muscle Nerve. 2014;49(4):584-92.

117. Colcombe S, Kramer AF. Fitness effects on the cognitive function of older adults: a meta-analytic study. Psychol Sci. 2003;14(2):125-30.

118. Stiggelbout M, Popkema DY, Hopman-Rock M, de Greef M, van Mechelen W. Once a week is not enough: effects of a widely implemented group based exercise programme for older adults; a randomised controlled trial. J Epidemiol Community Health. 2004;58(2):83-8.

119. Cakar E, Dincer U, Kiralp MZ, Cakar DB, Durmus O, Kilac H, et al. Jumping combined exercise programs reduce fall risk and improve balance and life quality of elderly people who live in a long-term care facility. Eur J Phys Rehabil Med. 2010;46(1):59-67.

120. Chapman SB, Aslan S, Spence JS, Defina LF, Keebler MW, Didehbani N, et al. Shorter term aerobic exercise improves brain, cognition, and cardiovascular fitness in aging. Front Aging Neurosci. 2013;5:75.

121. Hollmann W, Struder HK, Tagarakis CV, King G. Physical activity and the elderly. European journal of cardiovascular prevention and rehabilitation : official journal of the European Society of Cardiology, Working Groups on Epidemiology \& Prevention and Cardiac Rehabilitation and Exercise Physiology. 2007;14(6):730-9.

122. Booth FW, Roberts CK, Laye MJ. Lack of exercise is a major cause of chronic diseases. Comprehensive Physiology. 2012;2(2):1143-211.

123. Haskell WL, Lee IM, Pate RR, Powell KE, Blair SN, Franklin BA, et al. Physical activity and public health: updated recommendation for adults from the American College of Sports Medicine and the American Heart Association. Circulation. 2007;116(9):1081-93. 
Sardeli A. V. \& Gáspari A. F. \& Santos W. M. \& Moraes D. F. G. \& Gadelha V. B. \& Santos L. C. \& Ferreira M. L. V. \&

Prudêncio S. M. J. \& Bonfante I. L. P. \& Rodrigues B. \& Cavaglieri C. R. \& Fernhall B. \& Chacon-Mikahil M. P. T.

\section{Corresponding author}

Amanda Veiga Sardeli

Laboratory of Exercise Physiology, FISEX, Faculty of Physical Education, University of Campinas, Av Érico Veríssimo, 701 CEP 13083-851, PO Box 6134, Campinas, Brazil.

E-mail: amandaveigasardeli@yahoo.com.br
Manuscript received on April 11, 2018

Manscript accepted on July 31, 2018

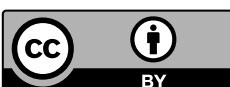

Motriz. The Journal of Physical Education. UNESP. Rio Claro, SP, Brazil - eISSN: 1980-6574 - under a license Creative Commons - Version 3.0 